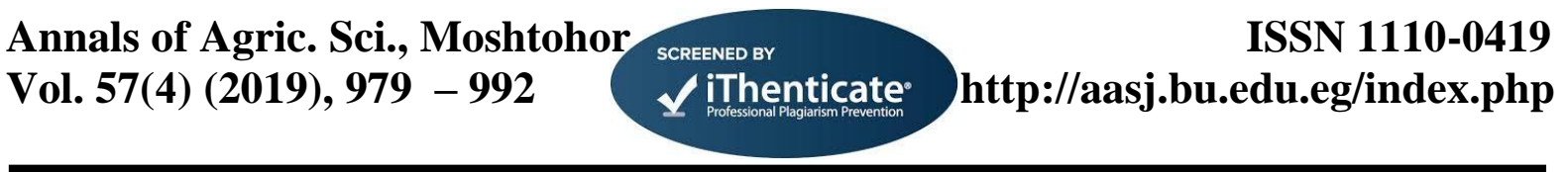

\title{
Breeding Cucumber (Cucumis sativus L.) for Spotted Spider Mite (Tetranychus urticae) Resistance
}

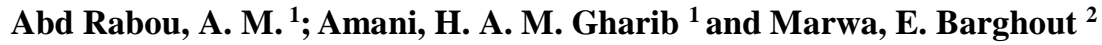 \\ Vegetables, Medicinal and Aromatic Plant Breeding Department, Hort. Res. Inst, \\ Agricultural Research Center (ARC), Giza, Egypt. \\ Acarology and Pests Plant Protection Department, National Research Center. \\ Corresponding author: amani2468@gmail.com
}

\begin{abstract}
Tetranychus urticae (Koch) is important pests of cucumber (Cucumis sativus L.). In this context, the aim of this study was finding resistance sources in ten cucumber accessions from different genetic resources (3 from Gene bank in Netherland, 4 from Nord Gene bank in Sweden and 3 from Main Vegetables and Hybrids Production Project in Egypt). The evaluation of resistance to T. urticae (Koch) and bitter taste in the inbred lines was carried out under greenhouse in the Department of Vegetables Crops, HRI, Dokki, Giza, during April - May 2017. INDIA110, CHINA-86 and EGY-118 inbred lines showed the least number of eggs and adults and less damage for $T$. urticae infection per leaf, EGY-112, EGY-114 and CHINA-117 inbred lines showed low infection and resistance. The other inbred lines showed highly infection. The evaluations for bitter showed that foliage of five inbred lines were bitter, INDIA-110 and CHINA-86 (high resistance), EGY-112 and CHINA-117 (resistance) and GUTA-105 (susceptible). The other inbred lines were bitter free where two of them were high resistant and resistant, (EGY 118 and EGY-114, respectively. INDIA-110, CHINA-86 and EGY-118 were selected as resistant parents to produce 6 hybrids using half-diallel mating design during July 2017. The results indicated that CHINA-100 and its hybrids were highly infected. On the other hand, INDIA-110, CHINA-86 and EGY-118 as well as their hybrids were high resistant. These results refer that the crossing between resistant $\times$ resistant is good specific combiner. The results of bitter taste showed that bitterness is dominance in all resistant hybrids. The other genetic studies for horticultural traits showed that EGY-118 inbred line appears good general camping.
\end{abstract}

Key words: Cucumber, Inbred lines, spotted spider mite (Tetranychus urticae)resistance, Half Diallel.

\section{Introduction}

Tetranychus urticae Koch (TSSM) especially under hot and dry conditions is important pests of greenhouse cucumbers, (Hussey and Parr 1963 and Hussey and Scopes 1985). (TSSM) is adapted to several environmental conditions and the greenhouses are model areas for that, which can complete a generation in one week (Düzgünes and Çobano_lu. 1983). In cucurbits the yield losses are primarily due to feeding on the lower leaf surfaces and thereby reducing the area of photosynthetic activity and in severe infestations causing leaf abscission (Ragkou $\boldsymbol{e t}$ al., 2004). The control by using acaricides is extremely difficult against when considering its capacity of developing resistance to acaricides, high reproductive potential, genetic resistance and short life cycle (Hoyt et al. 1985, Gracen et al. 1986 and Grazzini et al. 1997). Host-plant resistance to TSSM has been reported in different crops such as strawberry, raspberry and tomato (Wilde et al. 1991, Gimenez-Ferrer et al. 1994 and Saeidi and Mallik 2006). The injury caused in greenhouse production within the genus Cucumis mite resistance research has focused on the cucumber (Cucumis sativus L), Tulisalo 1972. Plant resistance to a pest can be by antixenosis, antibiosis, tolerance or some mechanisms, therefore, conducted choice tests to establish antixenosis (or non-preference) in which the plant is a poor host to the insect (Smith 2005). The terpenoids have been shown to be involved in both indirect and direct plant defense. The cucurbitacins is important example of direct defense compounds and the bitter triterpenoid compounds are toxic to most organisms including mammals such as man and specially wild and cultivated Cucurbitaceae (Mir, 1995). Several different forms of cucurbitacins have been identified, all with the general cucurbitane carbon skeleton: 19-(10->9)-abeo-10-lanost- 5-ene (Chao Che n 2005). Resistance was initially linked to the presence of some cucurbitacins in the foliage but results are inconsistent (Balkema-Boomstra. et al., 2003).

Balkema-Boomstra et al. (2003) confirmed the role of cucurbitacin bitter gene (cucurbitacin-C) in the host plant ( $C$. sativus) to be responsible for resistance to the two-spotted spider mites. The gene $B i$ confers bitterness to the entire plant that could be determined in the cotyledons. Cucumber has non-bitter fruits and bitter foliage, but fruits may become bitter under stress. In a preliminary study with dihaploid (completely homozygous) progenies from the F1 generation of a cross between the non-bitter, susceptible inbred line G6 and the resistant bitter accession 9140 where noticed an absolute link between spider mite resistance and bitterness in cucumber. All non-bitter tasting dihaploid lines were highly susceptible mean while the bitter-tasting 
dihaploid lines were shown to be resistant. Pierce and Wehner (1990) noticed that the $B i$ gene confers bitterness to the entire plant while the plants with bi (the recessive allele) are bitter-free.

The discovery of bitterness biosynthesis, regulation and domestication in cucumber provides possibility to develop a new non-bitter cucumber by accurately tuning the bitterness biosynthesis in different plant tissues, which protect plants from herbivores with their own weapon systems but avoid the unpleasant bitter taste in the fruit (Xiao, 2015).

The objective of this study was to evaluate resistance in cucumber inbred lines to the two-spotted spider mite and bitter-taste for cucumber foliage.
Also, study some economical traits as well as the genetic studies for all these traits.

\section{Materials and Methods}

This study was conducted to introduce some cucumber inbred lines for two-spotted spider mite, Tetranychus urticae (Koch) resistance, evaluate cucumber inbred lines to the bitter-taste for any possible variation in term of resistance among them and the role of bitterness to resistance in cucumber to the two-spotted spider mite, besides good horticultural characters. The used breeding materials included 10 different inbred lines of cucumber (Cucimus sativus L.), sources are illustrated in Table 1.

Table 1. Sources of used cucumber accessions in the current study.

\begin{tabular}{ccc}
\hline Genotype & CODE & Source \\
\hline CHINA-86 & Line1 & CGN \\
TAG-99 & Line 2 & CGN \\
CHINA-100 & Line 3 & NGB \\
GUAT-105 & Line 4 & CGN \\
INDIA-107 & Line 5 & NGB \\
INDIA-110 & Line 6 & NGB \\
EGY-112 & Line 7 \\
EGY-114 & Line 8 & (I.M.V.H.P.P) \\
CHINA-117 & Line 9 & (I.M.V.H.P.P) \\
EGY-118 & Line 10 & NGB \\
\hline
\end{tabular}

$\mathrm{CGN}=$ Gene bank of Netherland, NGB= Nord Gene bank (Sweden) and I.M.V.H.P.P = Main Vegetables and Hybrids Production Project.

\section{Inoculation with $T$. urticae:}

The evaluation of resistance to T. urticae (Koch) in the inbred lines was carried out under greenhouse in Vegetable, Aromatic and Medical plants Department Research, HRI, Dokki, Giza, during April - May 2017. Cucumber plants per accession were in plastic pots $(15 \mathrm{~cm}$ diameter and $15 \mathrm{~cm}$ deep). In each trial randomized complete block design (RCBD) was established for 10 treatments with 3 replicates, each replicate consisted of 10 plots, each plot contained 3 pots and each pots consisted 3 plants. At two-leaf stage one set of all the test cucumber plants were inoculated with spider mites as described by Ullah $\boldsymbol{e t}$ al. (2006). These plants provided mature females for egg production on the required leaf disc of the tested cultivars were collected from infected cucumbers from Kaha, Vegetable Research Farm. Cucumber leaves were taken for two times ( 25 and 40 days from sowing) and evaluated in the Acarology Laboratory, Acarology and Pests Plant Protection Department, National Research Center. The numbers of eggs and Adults were counted and recorded, After six weeks of infestation, plant damage was scored using 1-5 damage rating scheme of De Ponti (1977) where, $1=$ slight damage (1-20\%) and $5=$ heavy damage (80-100\%).

\section{Evaluation for horticultural characteristics}

Three resistant parents (CHINA-86, INDIA-110 and EGY-118) were selected out of this experiment as they showing resistance to $T$. urticae. They were used in crossing in addition to one susceptible parent (CHINA-100) to produce 6 hybrids using half-diallel mating design during July 2017 to study genetic on $T$. urticae resistance and other traits. The evaluation of resistance of the 4 inbred lines and 6 produced hybrids and the genetic study to $T$. urticae resistance and bitter taste was carried out during April 2018. The evaluation of horticultural traits was carried out in greenhouse at Kaha, Vegetable Research Farm, Qalubia governorate, Egypt during May 2018 and 2019.

The horticultural evaluation data were recorded as follows:

Average main stem length $(\mathrm{cm})$

The Average main stem length was measured in centimeters from the cotyledon node to the top end after 2 months from transplanting.

Leaf area $\left(\mathrm{cm}^{2}\right)$

Using cant meter $(\mathrm{cm} 2)$ produced by Li-cor, Pensylvania (Leaf area number 5 from the down of plant).

\section{Number of leaves}

Counting of leaves begin from the cotyledon node to the top end after 2 months from transplanting on the main stem.

\section{Number of fruit / plant}

First five harvests. 


\section{Fruit length(cm)}

The Average fruit length was measured in centimeters.

\section{Foliage Bitterness Evaluation}

Foliage bitterness was evaluated using tasting method described by Andeweg and DeBruyn (1959). Evaluation of foliage bitterness was conducted by tasting the cotyledons of seedlings or mature leaves. Balkema-Boomstra et al. (2003) referred that the gene $B i$ confers bitterness to the entire plant that could be determined in the cotyledons also.

\section{Statistical analysis}

All obtained data from the two seasons were subjected to the statistical analysis according to Steel and Torrie (1960). The Least Significant Differences (LSD) was computed at the 5\% level to compare the determined averages.

\section{Estimation of genetic parameters}

Heterosis over mid parent (MP), high parent (HP) and best parent (BP, over all used parents) for the studied traits was calculated according to the following formula adopted by Sinha and Khanna, 1975. Heritability was calculated using the equation by Allard, 1960. Potence ratio (relative potency of gene set) was used to determine the direction of dominance by Smith, 1952. General (GCA) and specific (SCA) combining abilities effects were estimated according to Griffing's (1956) model two of method two, which depends on use of some parental inbred lines and their $\mathrm{F}_{1}$ 's in one direction. Correlation coefficients were worked out to determine the degree of association among the characters as well as yield. This was done according to the formula given by Al-Jibouri et al. (1958). Test of significance of correlation was done by comparing the computed values against table ' $r$ ' values given by Fisher and Yates (1963).

\section{Results and Discussion}

Obtained data on the reaction of cucumber genotypes evaluated for $T$. urticae resistance under natural infection conditions and bitterness taste April, 2017 season are presented in Fig (1) and Fig (2). Among 10 cucumber inbred lines, three inbred lines showed the least number of eggs and adults for $T$. urticae infection per leaf, and were high resistance from infection, their number of eggs and adults per leaf were 1.22 for INDIA-110, 1.67 for CHINA-86 and 2.67 for EGY-118. Three inbred lines showed low infection, and were resistance, 5.5 for EGY-112, 17.92 for EGY-114 and 11.13 for CHINA-117.The other inbred lines showed highly infection and the number of eggs and adults for $T$. urticae were between 40.77 and 208.03 per leaf.



Fig. (1): The highest cucumber inbred lines of percent of T. urticae infection (eggs and adults) in the 2017 season.

On the other hand, the assessment of foliage bitterness for inbred lines were consistent over the April 2017 (Fig. 2) in total 45 plants of each inbred line were investigated. Foliage of 5 inbred lines were bitter, two of them were high resistant (INDIA-110 and CHINA-86) and two were resistance (EGY-112 and CHINA-117) besides the last one was susceptible (GUTA-105). The other inbred lines were bitter free, two of them were high resistant and resistant, EGY118 and EGY-114, respectively.

These results agreed with Dahillon (1992) who tested 16 lines of cucumber for two seasons where found some lines has bitter leaves and resistance to the two-spotted spider mites, but also found some lines has bitter free leaves and susceptible which referred that bitterness is not important for resistance to the two-spotted spider mites. While, 
these results disagreed with Balkema-Boomstra et al. (2003) which confirmed that bitter gene (cucurbitacin-C) in the host plant ( $C$. sativus) was responsible for resistance to the two-spotted spider mites.

Ullah, et al. (2006) found in one of the cucumber genotypes, (Dol pung Dado Gi), sticky materials were produced in response to the mites feeding (data not given).This material glued the mouthparts of the mites then the mite would die away of starvation.
There is a need for further investigation on the nature of such material, which will serve as additional source of resistance in the cucumbers like chemical or morphological defenses.

Based on the above results, 3 inbred lines (high resistant) INDIA-110, CHINA-86 and EGY-118 and one (high susceptible) CHINA-100 had been intercrossed in half diallel mating to obtain 6 cucumber hybrids (arranged in Table (2), to study the quality and genetic characters.



Fig. 2. The relation between bitter foliage and damage rating response of cucumber inbred lines in the 2017 season.

Table 2. The used genotypes in studying the quality and genetic characters.

\begin{tabular}{cc}
\hline LINE & CODE \\
\hline CHINA-86 & L1 \\
CHINA-100 & L3 \\
INDIA-110 & L6 \\
EGY-118 & L10 \\
CHINA-86 X CHINA-100 & L1xL3 \\
INDIA-110 X INDIA-110 & L1xL6 \\
CHINA-86 X EGY-118 & L1xL10 \\
CHINA-100 X INDIA-110 & L3xL6 \\
CHINA-100 X EGY-118 & L3xL10 \\
INDIA-110 X EGY-118 & L6xL10
\end{tabular}

\section{Evaluation for $T$. urticae infection}

Obtained data for $T$. urticae resistance and bitterness taste under greenhouse, May 2018 season of 10 genotypes are presented in Fig (3), (4) and Table (3). The results indicated that CHINA-100 and its hybrids were highly infected. On the other hand, CHINA-86, INDIA-110andEGY-118 and their hybrids were high resistant. These results refer that the crossing between resistant $\times$ resistant is good specific combiner. 


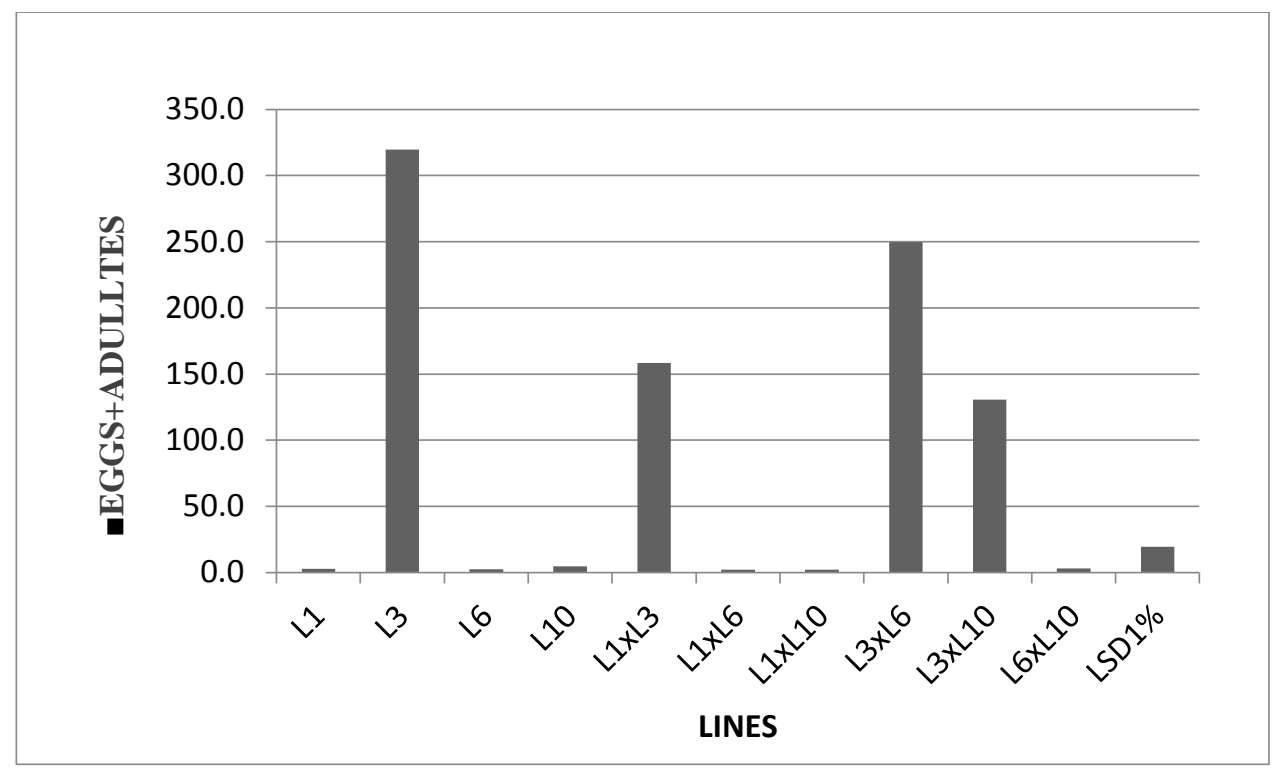

Fig. (3): The highest cucumber genotypes of percent of T. urticae infection (eggs and adults) in the 2018 season.

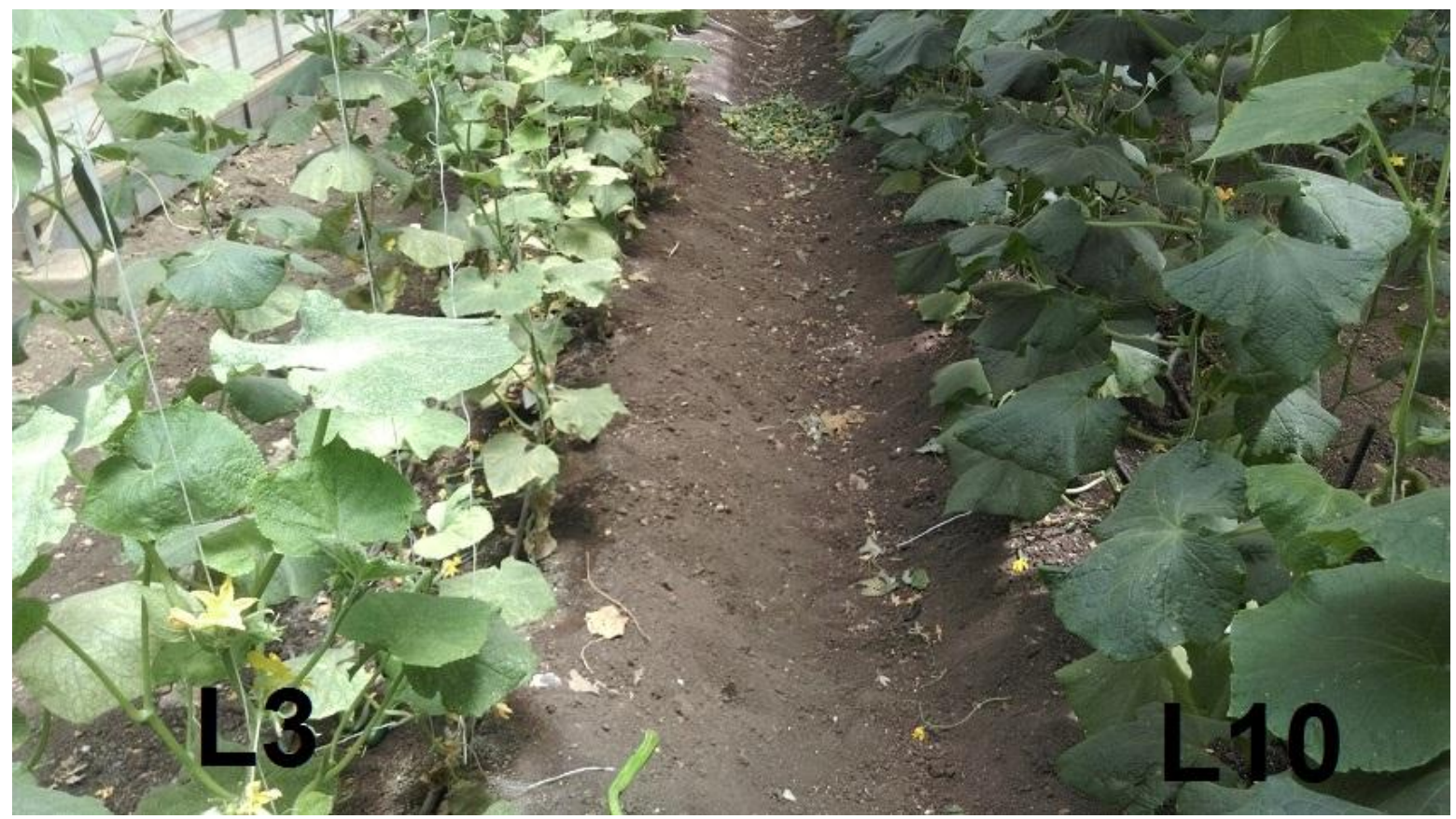

Fig. (4): Comparison between resistant plants (L10) and susceptible plants (L3)

On the other hand, the assessment of foliage bitterness for genotypes were consistent over the May 2018 (Fig. 5), the results refer that the hybrid which has one bitter parent was bitter. So that, all resistant hybrids were bitter. these results agreed with
Balkema-Boomstra et al. (2003) which confirmed that bitter gene (cucurbitacin-C) in the host plant $(C$. sativus) was responsible for resistance to the twospotted spider mites 


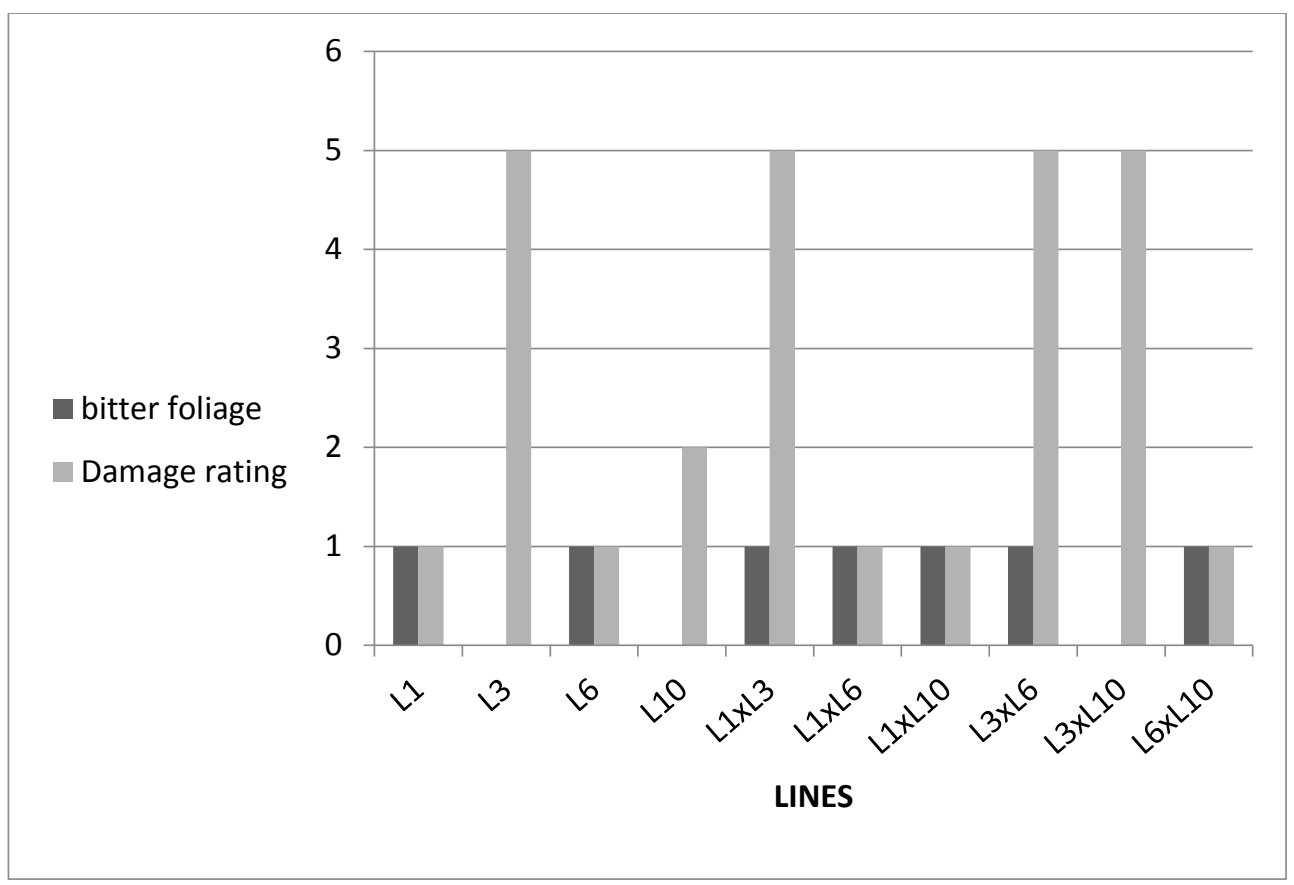

Fig. (5): The relation between bitter foliage and damage rating response of cucumber inbred lines in 2017 season

The results in Table (3) indicated that the potence ratio of 3 produced hybrids were negative between (.02 to -1.82 ) indicating partial dominance and over dominance of this character towards the susceptible parent. On the contrary, the other hybrids showed partial dominance and over dominance towards the resistant parent.

Table 3. Percent of T. urticae infection (eggs and adults) in seasons 2018 and genetic parameters.

\begin{tabular}{|c|c|c|c|c|c|}
\hline Genotypes & 2018 & Mid parent & Potence ratio & МРН\% & ВРН\% \\
\hline L1 & 2.81 & & & & \\
\hline L3 & 319.55 & & & & \\
\hline L6 & 2.38 & & & & \\
\hline L10 & 4.64 & & & & \\
\hline L1xL3 & 158.45 & 161.2 & -0.02 & -0.02 & -0.50 \\
\hline L1xL6 & 2.00 & 2.6 & 2.79 & -0.23 & -0.16 \\
\hline L1xL10 & 2.05 & 3.7 & -1.82 & -0.45 & -0.56 \\
\hline L3xL6 & 249.65 & 161.0 & 0.56 & 0.55 & -0.22 \\
\hline L3xL10 & 130.60 & 162.1 & -0.20 & -0.19 & -0.59 \\
\hline L6xL10 & 3.00 & 3.5 & 0.45 & -0.15 & 0.26 \\
\hline LSD & 19.4 & & & & \\
\hline
\end{tabular}

\section{Evaluation for horticultural characters}

This study was conducted in greenhouse during two seasons of 2018 and 2019. Ten cucumber genotypes (4 parents and 6 hybrids) were used in this study.

\section{Main Stem Length:}

Obtained data on plant main stem length after 2 months from sowing for 10 genotypes in 2018 and
All the mid and better parent heterosis of hybrids were negative and less than 1 (except mid parent of CHINA-86 x EGY-118 was 0.55)
2019 are presented in Fig (6) and Table (4). The results indicated that CHINA-100 and EGY-118 had higher main stem length than the other parents with significant differences and hybrids CHINA-86 $\times$ EGY-118 and CHINA-100 $\times$ EGY-118 had higher main stem length than the other hybrids. These results refer that the parents EGY-118 is good general combiner. 




Fig. (6): Average main stem length of cucumber genotypes evaluated in 2018 and 2019.

The results indicated that the potence ratio of 3 produced hybrids were higher than 1 indicating over dominance of this character towards the long parent. On the contrary, the other hybrids showed partial dominance towards the short parent.

The mid parent and better heterosis of three hybrids were positive and ranged from $>0$ to $<1$ and the other three hybrids were negative and ranged from $>-1$ to $<0$. These results agreed with Nienhuis and Lower (1980) who found that most of the variation in population of cucumber was due to dominant effects. They observed heterosis above the high parent for main stem vine length.

Table 4. Genetic parameters and average main stem length $(\mathrm{cm})$ of cucumber genotypes in seasons 2018 and 2019.

\begin{tabular}{|c|c|c|c|c|c|c|}
\hline Genotypes & 2018 & 2019 & Mid & Potence & МРН\% & ВРН\% \\
\hline $\mathrm{L} 1$ & 102.2 & 103.6 & & & & \\
\hline L3 & 115.4 & 116.7 & & & & \\
\hline L6 & 83.8 & 85.1 & & & & \\
\hline L10 & 118.4 & 120.4 & & & & \\
\hline L1xL3 & 104.3 & 108.9 & 108.8 & -0.69 & -0.04 & -0.10 \\
\hline L1xL6 & 108.5 & 111.2 & 93.0 & 1.68 & 0.17 & 0.06 \\
\hline L1xL10 & 140.8 & 142.8 & 110.3 & 3.79 & 0.28 & 0.19 \\
\hline L3xL6 & 99.0 & 103.3 & 99.6 & -0.04 & -0.01 & -0.14 \\
\hline L3xL10 & 145.9 & 144.9 & 116.9 & 19.36 & 0.25 & 0.23 \\
\hline L6xL10 & 98.4 & 104.4 & 101.1 & -0.15 & -0.03 & -0.17 \\
\hline LSD & 3.9629 & 4.463 & & & & \\
\hline
\end{tabular}

\section{Number of leaves}

Values leaves of number presented in Fig. (7). L3 was the higher number of leaves with significant differences between it and the otherinbred lines in both two seasons.Also, hybridCHINA-86 × CHINA100 was the higher number of leaves in twoseasons.
The genetic results in Table (5) indicated that the potence ratio of 3 hybrids refer to over dominance for this character towards the higher parent. On the other hand, one of them refer to over dominance and two hybrids refer to partial dominance towards the lower parent. 




Fig. (7): Average number of leaves of cucumber genotypes evaluated in 2018 and 2019 seasons.

The mid parent heterosis values of all hybrid were positive and ranged between 0 and 0.3 , while, better parent heterosis of all hybrids (except CHINA-100 $\times$ INDIA-110 and CHINA-100 $\times$ EGY-118) were 0.1.

Table 5. Genetic parameters and average number of leaves of cucumber genotypes in seasons 2018 and 2019.

\begin{tabular}{|c|c|c|c|c|c|c|}
\hline Genotypes & 2018 & 2019 & $\begin{array}{c}\text { Mid } \\
\text { parent }\end{array}$ & $\begin{array}{c}\text { Potence } \\
\text { ratio }\end{array}$ & МРН\% & ВРН\% \\
\hline L1 & 17.7 & 19.0 & & & & \\
\hline L3 & 21.0 & 22.3 & & & & \\
\hline L6 & 13.7 & 15.0 & & & & \\
\hline L10 & 18.7 & 20.7 & & & & \\
\hline L1xL3 & 22.7 & 24.7 & 19.3 & 2.0 & 0.2 & 0.1 \\
\hline L1xL6 & 19.7 & 21.0 & 15.7 & 2.0 & 0.3 & 0.1 \\
\hline L1xL10 & 20.3 & 22.3 & 18.2 & -4.3 & 0.1 & 0.1 \\
\hline L3xL6 & 16.7 & 18.0 & 17.3 & -0.2 & 0.0 & -0.2 \\
\hline L3xL10 & 19.0 & 18.0 & 19.8 & -0.7 & 0.0 & -0.1 \\
\hline L6xL10 & 21.3 & 23.3 & 16.2 & 2.1 & 0.3 & 0.1 \\
\hline LSD & 1.5 & 1.6 & & & & \\
\hline
\end{tabular}

\section{Average leaf area}

Obtained data on the leaf area $\left(\mathrm{cm}^{2}\right)$ of 10 cucumber genotypes in two seasons are presented in Fig. (8). The results indicated that line CHINA-100 was significantly the highest in leaf area in both seasons. The results revealed that the hybrid CHINA$100 \times$ INDIA-110 gave the highest leaf area compared with the other hybrids in both seasons. 


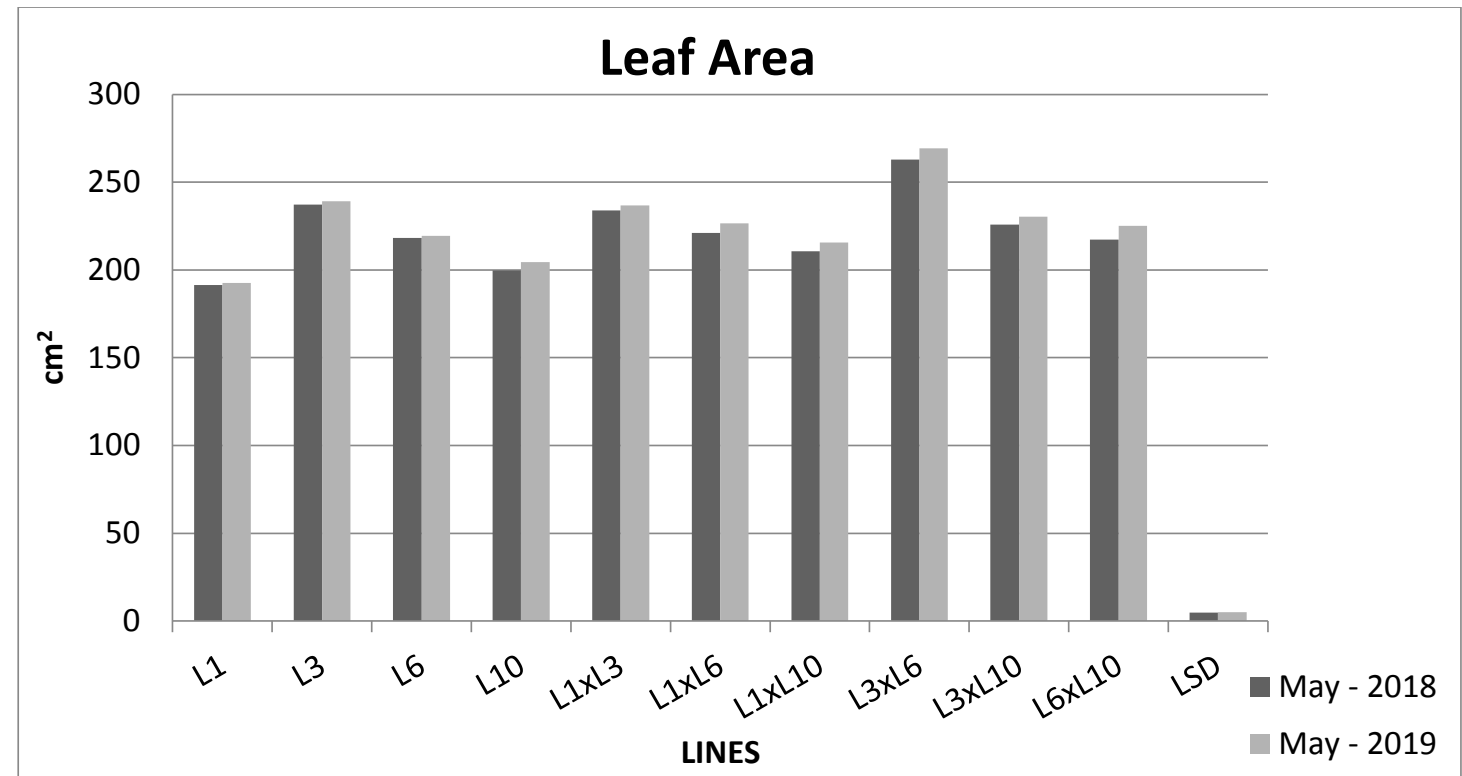

Fig. (8): Average leaf area of cucumber genotypes evaluated in 2018 and 2019seasons.

The results in Table (6) also indicated that the potence ratio for all produced hybrids(expect CHINA$100 \times$ EGY-118 was 0.7) were higher than 1 indicating over dominance towards the high parent for this character. While, all hybrids exhibited partial dominance towards the mid parent. On the other hand the hybrids CHINA-86 $\times$ EGY-118, CHINA-100 $\times$ INDIA-110 and INDIA-110 $\times$ EGY-118 gave partial dominance towards the highest parent.

Table (6): Genetic parameters and average number of leaves of cucumber genotypes in seasons 2018 and 2019.

\begin{tabular}{|c|c|c|c|c|c|c|}
\hline Genotypes & 2018 & 2019 & $\begin{array}{c}\text { Mid } \\
\text { parent }\end{array}$ & $\begin{array}{c}\text { Potence } \\
\text { ratio }\end{array}$ & МРН\% & ВРН\% \\
\hline L1 & 191.3 & 192.6 & & & & \\
\hline L3 & 237.2 & 239.2 & & & & \\
\hline L6 & 218.2 & 219.5 & & & & \\
\hline L10 & 199.7 & 204.4 & & & & \\
\hline L1xL3 & 233.8 & 236.8 & 209.8 & 1.5 & 0.2 & 0.0 \\
\hline L1xL6 & 221.1 & 226.5 & 199.9 & 1.4 & 0.1 & 0.0 \\
\hline L1xL10 & 210.7 & 215.6 & 193.0 & 3.9 & 0.1 & 0.1 \\
\hline L3xL6 & 262.9 & 269.2 & 222.4 & 3.5 & 0.2 & 0.1 \\
\hline L3xL10 & 225.9 & 230.2 & 215.5 & 0.7 & 0.1 & 0.0 \\
\hline L6xL10 & 217.2 & 225.2 & 205.6 & 2.7 & 0.1 & 0.1 \\
\hline LSD & 4.8 & 5.1 & & & & \\
\hline
\end{tabular}

\section{Number of fruit/plant}

The results of number of fruit/plant (Fig. 9) showed that CHINA-86 was the highest parent with significant differences comparing to the other parents.
Also, CHINA-100 × EGY-118 was the highest hybrid with significant differences comparing to the other hybrids. 


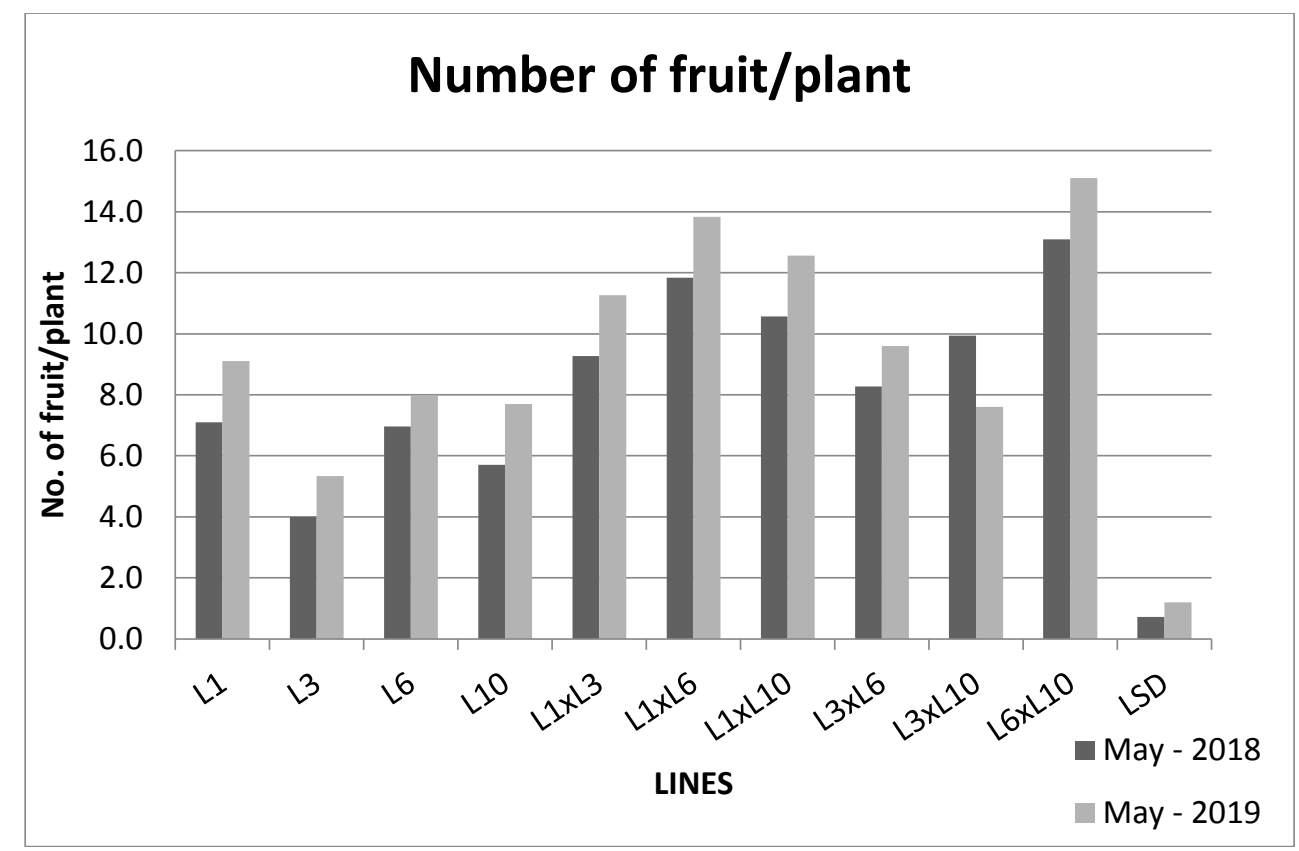

Fig. (9): Average number of fruits/plant of cucumber genotypes evaluated in 2018 and 2019seasons.

The genetic results (Table 7) indicated that the potence ratio of all hybrids refer to over dominance for this character towards the high parent. The mid parent heterosis values of all hybrid were positive and ranged between $0-1.1$. While, better parent hetrosis for all hybrids were positive and ranged between 0.2 -0.9 .

Table (7): Genetic parameters and average number of fruit/plant of cucumber genotypes in seasons 2018 and 2019.

\begin{tabular}{|c|c|c|c|c|c|c|}
\hline Genotypes & 2018 & 2019 & $\begin{array}{c}\text { Mid } \\
\text { parent }\end{array}$ & $\begin{array}{c}\text { Potence } \\
\text { ratio }\end{array}$ & МРН\% & ВРН\% \\
\hline L1 & 7.1 & 9.1 & & & & \\
\hline L3 & 4.0 & 5.3 & & & & \\
\hline L6 & 7.0 & 8.0 & & & & \\
\hline L10 & 5.7 & 7.7 & & & & \\
\hline L1xL3 & 9.3 & 11.3 & 5.6 & 2.4 & 0.7 & 0.3 \\
\hline L1xL6 & 11.8 & 13.8 & 7.0 & 72.0 & 0.7 & 0.7 \\
\hline L1xL10 & 10.6 & 12.6 & 6.4 & 6.0 & 0.7 & 0.5 \\
\hline L3xL6 & 8.3 & 9.6 & 5.5 & 1.9 & 0.5 & 0.2 \\
\hline L3xL10 & 9.9 & 7.6 & 4.9 & 6.0 & 1.0 & 0.7 \\
\hline L6xL10 & 13.1 & 15.1 & 6.3 & 10.7 & 1.1 & 0.9 \\
\hline LSD & 0.7 & 1.2 & & & & \\
\hline
\end{tabular}

Fruit length

Results of average fruit length (cm) (Fig. 10) showed that EGY-118 and its hybrids (EGY-118 $\times$ INDIA110, EGY-118 $\times$ CHINA100 andEGY-118 $\times$
CHINA-86, respectively)were the highest genotypes with significant differences compared with other genotypes in both seasons. 




Fig. (10): Average fruit length (cm) of cucumber genotypes evaluated in 2018 and 2019 seasons.

Results in Table (8) indicated that the potence ratio of all hybrids refer to over and partial dominance for fruit length character towards the lower parent. The mid parent heterosis values of all hybrids were positive and ranged between $0.13-0.32$. While, better parent hetrosis of all hybrids were positive and ranged between $0.01-0.12$, except the hybrid CHINA-86 $\times$ EGY-118 which was -0.12 .

Table 8. Genetic parameter and average fruit length (cm) cucumber genotypes in seasons2018 and 2019.

\begin{tabular}{ccccccc}
\hline Genotypes & $\mathbf{2 0 1 8}$ & $\mathbf{2 0 1 9}$ & $\begin{array}{c}\text { Mid } \\
\text { parent }\end{array}$ & $\begin{array}{c}\text { Potence } \\
\text { ratio }\end{array}$ & MPH\% & BPH\% \\
\hline L1 & 12.8 & 13.2 & & & & \\
L3 & 15.5 & 16.3 & & & & \\
L6 & 16.4 & 17.1 & & & & \\
L10 & 23.3 & 24.1 & & & & \\
L1xL3 & 17.0 & 17.3 & 14.2 & -2.13 & 0.20 & 0.10 \\
L1xL6 & 17.4 & 16.6 & 14.6 & -1.54 & 0.19 & 0.06 \\
L1xL10 & 20.5 & 20.3 & 18.1 & -0.46 & 0.13 & -0.12 \\
L3xL6 & 18.2 & 18.3 & 16.0 & -4.86 & 0.14 & 0.11 \\
L3xL10 & 23.5 & 23.5 & 19.4 & -1.04 & 0.21 & 0.01 \\
L6xL10 & 26.2 & 24.9 & 19.9 & -1.84 & 0.32 & 0.12 \\
LSD & 1.4 & 1.1 & & & & \\
\hline
\end{tabular}

\section{Combining ability}

Combining ability is useful in successful prediction of genetic capability of parental lines and crosses (Singh et al., 2013).

General combining ability (GCA) for traits of lines (Table 9) showed that CHINA-86 had negative GCA effect for all traits except number of fruits and number of leaves. Furthermore, it was observed that the GCA of CHINA-100 was positive and significantly higher than the other lines in resistance to spider mite and significant in number of leaves and stem length, but it is was negative and significantly higher in number of fruits and significant in fruit length.

All lines showed positive and non-significant GCA except CHINA-100 which was significant positive, while CHINA-100 and EGY-118 were good general combiners for most studied traits. 
Table 9. General combining ability (GCA) estimates of some quantitative traits in used cucumber parents.

\begin{tabular}{ccccccc}
\hline Genotypes & Resistance & No. of fruits & No. of leaves & Stem length & Leaf area & Fruit length \\
\hline L1 & $-19.62^{*}$ & 0.42 & 0.44 & -0.04 & -7.41 & $-2.47^{*}$ \\
L3 & $57.78^{*}$ & $-1.32^{*}$ & $0.83^{*}$ & $3.59^{*}$ & 12.53 & $-0.98^{*}$ \\
L6 & $-20.08^{*}$ & 0.63 & $-1.72^{*}$ & $-14.13^{*}$ & 1.48 & -0.11 \\
L10 & $-18.08^{*}$ & $2.27^{*}$ & 0.44 & $10.59^{*}$ & -6.61 & $3.55^{*}$ \\
LSD 5\% & 4.25 & 2.16 & 1.31 & 3.67 & 24.11 & 0.61 \\
\hline
\end{tabular}

Specific combining ability (SCA) effects of resistance were high significant in all hybrids, while, it was negative in all hybrids of the parentCHINA100. The results arranged in Table (10) showed that SCA values for main stem length were high significant in all hybrids except CHINA-100 $\times$ INDIA-110 was not significant.

INDIA-110 $\times$ EGY-118 was the best hybrid in SCA with high significant in all traits except leaf area that was significant, flowed by CHINA- $86 \times$ INDIA110 which had SCA with high significant in all traits except leaf area showed no significant.

Results showed that the ratio of GCA/SCA was 0.6 for resistance to T. urticae indicating that non-additive gene effects for this characters. The potentiality of crossing between specific parents were detected by estimating specific combining ability (SCA) effects of $\mathrm{F}_{1}$ cross combinations for all studied traits.

Table 10. Specific combining ability (SCA)effects of some quantitative traits of studied cucumber $\mathrm{F}_{1}$ 's hybrids.

\begin{tabular}{ccccccc}
\hline Genotypes & Resistance & No. of fruits & No. of leaves & $\begin{array}{c}\text { Main stem } \\
\text { length }\end{array}$ & Leaf area & Fruit length \\
\hline L1 $\times$ L3 & $-51.91^{*}$ & 1.49 & $2.32^{*}$ & $-10.95^{*}$ & 21.16 & $1.37^{*}$ \\
L1×L6 & $13.02^{*}$ & $2.12^{*}$ & $1.88^{*}$ & $11.04^{*}$ & 19.55 & $0.90^{*}$ \\
L1 $\times$ L10 & $11.24^{*}$ & 1.20 & 0.38 & $18.62^{*}$ & 17.17 & 0.34 \\
L3×L6 & $-54.14^{*}$ & 0.28 & -1.51 & -2.13 & $41.37^{*}$ & 0.24 \\
L3×L10 & $-49.41^{*}$ & $2.30^{*}$ & -1.34 & $20.05^{*}$ & 12.46 & $1.62^{*}$ \\
L6×L10 & $12.51^{*}$ & $5.53^{*}$ & $3.54^{*}$ & $-9.70^{*}$ & $34.84^{*}$ & $3.72^{*}$ \\
LSD 5\% & 10.30 & 5.24 & 3.18 & 8.90 & 58.40 & 1.47 \\
Vgca/Vsca & 0.59 & 0.31 & 0.23 & 0.51 & 0.14 & 1.10 \\
\hline
\end{tabular}

The high significant GCA and SCA mean squares recorded in all the traits suggesting the importance of both additive and non-additive components of heritable variance which are responsible for observed variation in these traits. These findings were in line with the reports of Chikezie et al. (2019).

GCA/SCA ratio is less than one in all traits except fruit length, which showed the preponderance of non-additive gene effects in those traits with ratio less than one. This result was in conformity to the reports of Dogra and Kanwar (2011).

\section{Correlation}

Correlation levels were computed for all the 4 characters. The results are presented in Table 11.

\section{Main stem Length}

Main stem length showed positive and highly significant correlation with number of leaves and number of fruits/plant and significant correlation with leaf area and fruit length.

\section{Number of Leaves}

Number of leaves had positive and significant correlation with main stem length and leaf area, whereas no significant correlation with number of fruit/plant and fruit length.

\section{Leaf area}

In respect to this character, it had positive and high significant correlation with main stem length and significant number of leaves and fruit length, whereas no-significant correlation with number of fruits/plant. Number of fruit/plant

A high significant positive correlation level was observed for main stem length but no significant correlation with the other characters.

\section{Fruit length}

Fruit length had positive and significant correlation with main stem length and leaf area. Whereas, nosignificant correlation with number of leaves and number of fruits/plant were observed.

Table 11: Phenotypic correlation coefficients among 4 characters in cucumber

\begin{tabular}{lllll}
\hline Characters & $\begin{array}{l}\text { No. } \\
\text { Leaves }\end{array}$ & Leaf area & $\begin{array}{l}\text { No. } \\
\text { fruits/plant }\end{array}$ & Fruit length \\
\hline Main stem Length & $0.79^{* *}$ & $0.87^{*}$ & $0.23^{* *}$ & $0.41^{*}$ \\
No. of Leaves & & $0.56^{*}$ & -0.08 & 0.33 \\
Leaf area & & & 0.12 & $0.87^{*}$ \\
No. of fruits/plant & & & & 0.21 \\
LSD 5\%** & LSD 1\%* & & & \\
\hline
\end{tabular}


References

Al-Jibouri, H. A.; P. A. Miller and H. F. Robinson (1958). Genotypic and environmental variances in upland cotton cross of interspecific origin. Agronomy Journal, 50:633-636.

Allard, R. W. (1960). Principles of plant breeding. John Wiley \& Sons, Inc. 473p

Andeweg, J. M. and J. W. De Bruyn (1959). Breeding of non-bitter cucumbers. Euphytica. 8:13-20.

Balkema-Boomstra, A. G.; S. Zijlstra; F. W. A. Verstappen; H. Inggamer; P. E. Mercke; M. A. Jongsma and H. J. Bouwmeester (2003). Role of cucurbitacin-C in resistance to Spider mite (Tetranychus urticae) in Cucumber (Cucumis sativus L.) J. Chem. Ecol. 29(1): 225-235.

Chao Chen, J.; M. Hua Chiu; R. Lin Nie; G. A. cordell; S. X. Qiu (2005). Curbitacins and cucurbitan glycosides: structures and biological activities. The Royal Society of Chemistry 22:386399.

Chikezie, O. E.; E. O. Peter; U. A. Christian; P. C. Uchechukwu (2019). Heterosis and combining ability in cucumber (Cucumis sativus L.). Information processing in Agriculture, 150-157.

De Ponti, O. M. B. (1977). Resistance in Cucumis sativus L., to Tetranychus urticae Koch. Designing a reliable laboratory test for resistance based on aspects of the host- parasite relationship. Euphytica 26: 641-654.

Dhillon, N. P. S. (1992). Non-linkage of bitterness and resistance to red spider mite in cucumber. Cucurbit genetics cooperative report 15:31-32.

Dogra, B. S. and M. S. Kanwar (2011). Selecting parents for developing superior hybrids in cucumber (Cucumis sativus L.). Adv. Hort. Sci.,25(4):239-44.

Düzgünes, Z. and S. Çobano_lu (1983). The life history and tables Tetranychus urticae Koch and Tetranychus cinnabarinus (Boisduval) (Acarina: Tetyranychidae) under the various temperatures and humidities. Plant Protection Bulletin 23(4): 171-187.

Fisher, G. and M. Yates (1963). Statistical Tables for Biological, Agricultural and Medical Research, 6: 62-63.

Gimenez, F. R. M.; W. A. Erb; B. L. Bishop; J. C. Scheerens (1994). Host-pest relationship between the two spotted spider mite and strawberry cultivars with diVering levels of resistance. J Econ Entomol 87:168-175.

Gracen, V. E. (1986). Host plant resistance for insect control in some important crop plants. Crit. Rev. Plant Sci 4:277-291.

Grazzini, R. D. W.; J. Harmon; D. J. Hesk; D. CoxFoster; J. Medford; R. Craig; R. O. Mumma (1997). Inheritance of biochemical and morphological characters associated with two- spotted spider mite resistance in Pelargonium $\times$ hortorum. J. Am. Soc. Hort. Sci., 122: 373-379.

Griffing, B. (1956). Concept of general and specific combining ability in relation to diallel crossing systems. Aust. J. Biol. Sci. 9: 463-493.

Hoyt, S. C.; P. H. Westigard and B. A. Croft (1985). Cyhexatin resistance in Oregon populations of Tetranychus urticae Koch (Acarina: Tetranychidae). J. Econ. Entomol 78: 656-659.

Hussey, N. W. and W. J. Parr (1963). The effect of glasshouse red spider mite on the yield of cucumber. J. Hortic. Sci. 38: 255-263.

Hussey, N. W. and N. E. A. Scopes (1985). Mite management for greenhouse vegetables in Britain. In: Helle W, Sabelis M W (eds) Spider mites: their biology, natural enemies and control, vol $1 \mathrm{~B}$. Elsevier, Amsterdam, pp 285-297.

Mir, O. M. (1995). Cucurbitacins and their pharmacological effects. Phytother. Res 9: 159168.

Nienhuis, J. and R. L. Lower (1980). Gene effects of several characteristics in a cross between a pickling cucumber inbred (Cucumis sativus L.) and a Cucumis hardwickii R. HortScience. 15:420. Cited from Pl. Breed. Abstr. 51:76-86.

Pierce, L. K. and T. C. Wehner (1990). Review of genes and linkage groups in cucumber. Hort. Science 25: 605-615.

Ragkou, V. S.; C. G. Athanassiou; N. G. Kavallieratos; Z. Tomanovie (2004). Daily consumption and predation rate of different Stethorus punctillum instars feeding on Tetranychus urtica. Phtoparasitica 32:154-159.

Saeidi, Z. and B. Mallik (2006). In vitro screening of 67 Lycopersicon accessions/cultivars for resistance to two spotted spider mite. J Biol Sci., 6: 847-853.

Singh, A. K.; R. S. Pan and P. Bhavana (2013). Heterosis and combining ability analysis in bitter gourd (Momordica charantia L.). Bioscan; 8(4):1533-6.

Sinha, S. K. and R. Khanna(1975). Physiological, biochemical and genetic basis of heterosis. Adv. Agron. 27: 123-174.

Smith, C. M.(2005). Plant resistance to arthropods: molecular and conventional approaches. Springer, the Netherlands.

Smith, H. H. (1952). Fixing transgressive vigor in Nicotiana rustica. pdgs. 161-74 en Gowen, J.W. (ed.), Heterosis, Iowa State Coll., Ames, Iowa, EE. UU.

Steel, R. G. D. and J. H. Torrie (1960). Principles and Procedures of Statistics with Special Reference to the Biological Sciences. Mc Graw Hill Book Company. Inc. New York.

Tulisalo, U. (1972). Resistance to the two-spotted spider mite Tetranychus urtica Koch, (Acari: Tetranychidae) in the genera Cucumis and Citrullus (Cucurbitaceae) Ann. Ent. Fenn 38: 6064 
Ullah, F.; J. H. Lee and Farhatullh (2006). Evaluation of cucumber accession against twospotted spider mite. Songklanakarin J. Sci. Technol.Vol.28 No.4.

Wilde, G.; W. Thomas and H. Hall (1991). Plant resistance to two spotted spider mite (Acari:
Tetranychidae) in raspberry cultivars. J Econ Entomol 84: 251-255.

Xiao-Ya Chen (2015). Bitter but tasty cucumber. doi:10.1093/nsr/nwv018.https://www.researchgat e.net/publication/276142319

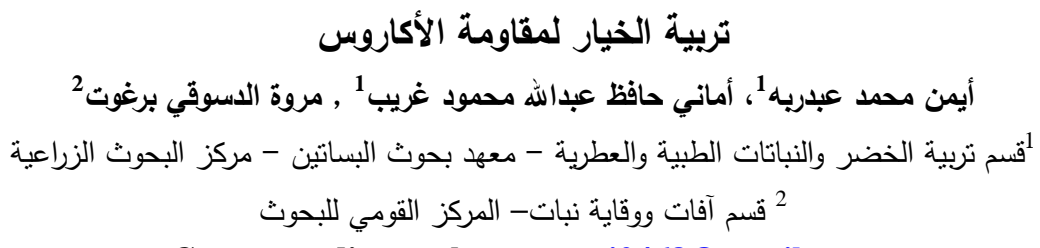

Corresponding author: amani2468@gmail.com

أجريت هذه الدراسة في الفترة من 2017- 2018 - 2019 بمعهد بحوث البساتين بالتعاون مع الثعبة الزراعية - المركز القومي للبحوث.

تهدف هذه الدراسة إلي توفير المعلومات الخاصة بصفة وراثة المقاومة للأكاروس في الخيار حتي بتمكن المربي من وضع وتتفيذ برنامج لتحسين

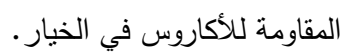

استخدامت في هذه الدراسة 10 سلالات مختلفة من الخيار تم الحصول عليها من مصادر مختلفة , وتم عمل تربية داخلية لها للتأكد من

الثبات والتجانس الوراثي لها في معهد بحوث البساتين. نم عمل عدوي طبيعيه بلأكاروس عند الورقة الحقيقيه الثالثة للنبات لهذه السلالات لإختبار درجة المقاومة للأكاروس والمرارة فيها وتم تقييم شدة الإصابة علئ علي النباتات.

$$
\text { أظهرت النتائج }
$$

أولاً:- السلالات INDIA-110 و EGY-118 CHINA-86 كانت بها مقاومة عالية للإصابة بالأكاروس حيث كان عليها أقل عدد

من البيض و أفراد الكاملة, كما أظهرت الثناث سلالات EGY-112 و EGY-114 و CHINA-117 درجة أقل من المقاومة, وكانت باقي السلالات حساسة للإصابة بالأكاروس.

ثانيا:- إرتبطت صفة المرارة في الأوراق بصفة المقاومة للأكاروس بدرجة كبيرة ,علي الرغم من إحدي السلالات (EGY-118) عالية

المقاومة كانت الأوراق عديمة المرارة و العكس كانت السلالة (GUTA-105) شديدة الحساسية للإصابة بالأكاروس مع أن أوراقها كانت بها مرارة

عالية.

ثالثاً:- استخدمت السلالات التي بها مقاومة عالية للإصابة بالأكاروس INDIA-110 و

CHINA-100 و هي حساسة للإصابة بالأكاروس لإجراء تهجين نصف دائري فيما بينها لإنتاج 6 هجن.

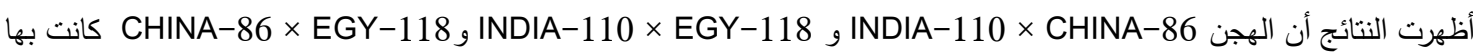

مقاومة عالية للإصابة بالأكاروس , كما أن الهجن التي كان أحد أبائها CHINA-100 حساس للإصابة بالأكاروس كانت كلها حساسة للإصابة بالأكاروس.

أظهر الاب EGY-118 أفضل قدرة علي التآلف من حيث المقاومة للإصابة بالأكاروس والصفات البستانية الجيدة, كما أظهر الهجين

والتآلف علي المستوي العام و يمكن إستخدامه كمصدر جيد للمقاومة مع إستمرار برنامج التربية.

وكان الهجين INDIA-110 × EGY-118 أفضل هجين له قدرة خاصة علي التآلف والصفات البستانية الجيدة.

ويتضح مما سبق أن التهجين بين سلالتين بهما مقاومة للإصابة بالأكاروس أفضل للحصول علي هجين خيار به مقاومة عن التهجين بين

سلاله بها مقاومة وآخري حساسة للإصابة. 